\title{
A banda desenhada histórica como um recurso pedagógico no ensino da História
}

\author{
The historical comics as a pedagogical resource in the teaching of \\ History
}

Tiago Cardoso ${ }^{1}$

Glória Santos Solé ${ }^{2}$

RESUMO

Neste trabalho apresentamos um estudo desenvolvido com alunos do 4.. ano de escolaridade (9-10 anos) de uma escola urbana do Norte de Portugal, em que se procurou que os alunos desenvolvessem aprendizagens significativas em História, numa perspetiva construtivista, através do modelo de aula-oficina, com recurso à exploração de Bandas Desenhadas Históricas (BDs) com perspetivas diferentes, relacionadas com a temática da "Expansão Marítima Portuguesa- a chegada ao Brasil". A partir deste modelo pedagógica, pretendeu-se dar resposta às questões de investigação: "Que conhecimento histórico os alunos extraem de uma Banda Desenhada?" e "Que conhecimento histórico os alunos aplicam na construção de uma Banda Desenhada?". A análise dos dados recolhidos permitiu-nos concluir que a utilização de Banda Desenhada Histórica contribuiu para o desenvolvimento da compreensão histórica nos alunos e promoveu o desenvolvimento de várias competências específicas em História, como a leitura e interpretação de fontes diversas e com mensagens divergentes, bem como competências transversais, ao nível da comunicação (área do Português e das Expressões)

Palavras-chave: Histórias em quadradinhos. Recurso pedagógico. Educação Histórica. Multiperspetividade.

\section{ABSTRACT}

In this work, we present a study carried out with students from the 4th year of schooling (9-10 years) of an urban school of Northern Portugal, in which students were expected to develop meaningful learning in History from a constructivist, through the classroom-workshop model, with the use of Historical Comics with different perspectives related to the theme of "Portuguese Maritime Expansion - the arrival in Brazil". From this pedagogical model, it was intended to answer the research questions: "What historical knowledge do students draw from a comic strip?" And "What historical knowledge do students apply to the construction of a comic strip?". The analysis of the collected data allowed us to conclude that the use of Historical Comics contributed to the development of historical understanding in students and promoted the development of several specific competences in History, such as reading and interpretation of diverse sources and with divergent messages as well as transversal competences, in terms of communication (Language and Expressions area).

Keywords: Comics. Pedagogical Resource. History Education. Multiperspectivity.

1 Mestre em Educação pela Universidade do Minho (Portugal)

2 Doutora em Educação. Professora do Instituto de Educação da Universidade do Minho (Portugal). Investigadora do Centro de Investigação em Educação. E-mail: gsole@ie.uminho.pt 


\section{Introdução}

Este artigo apresenta alguns pontos do projeto "A Banda desenhada histórica como recurso e fonte historiográfica para o ensino e a aprendizagem da História" (CARDOSO, 2016). Esta investigação consistiu em realizar na área disciplinar de Estudo do Meio, no ensino da História, a aplicação de Bandas Desenhadas (BDs) como fonte historiográfica e pedagógica a ser trabalhado com as crianças do 1. Ciclo do Ensino Básico.

Em primeiro lugar, neste artigo será apresentado um conjunto de visões que surgem de vários investigadores internacionais e nacionais, como por exemplo, (BONIFÁCIO, 2005; FRONZA, 2007, 2012; SOLÉ, 2009, 2011, 2013; ZINK, 1997, 1999) que apresentam várias perspetivas, relativamente à aplicação das bandas desenhadas históricas como um recurso didático, que possibilita o desenvolvimento da construção do conhecimento histórico das crianças.

Após esse referencial teórico, será exposta a experiência deste estudo empírico realizado com os 26 alunos do $4 . .^{\circ}$ ano de escolaridade, em contexto de sala de aula, aplicando-se bandas desenhadas históricas de autores e ilustradores portugueses e brasileiros sobre a "Expansão Marítima Portuguesa- a chegada ao Brasil" e solicitando a construção das suas próprias Bandas Desenhadas, tendo como referencial as obras e fontes exploradas ao longo do projeto.

No final, serão apresentados alguns dos resultados deste projeto, estando estes direcionados para o primeiro momento do projeto, no que diz respeito à construção do conhecimento histórico dos alunos, a partir da exploração das bandas desenhadas históricas e da construção e BDs sobre a abordagem histórica da "descoberta/achamento" do Brasil.

\section{A Investigação sobre Banda Desenhada Histórica}

A Banda Desenhada (BD), sendo um género literário de massas, e que permite abranger um vasto público, nomeadamente crianças, jovens e/ou adultos, a sua designação é bastante diversificada ao longo do globo. Em Portugal a forma mais frequente de referenciar esta tipologia é Banda Desenhada (BD), tendo influências da tradução do termo francês "bande dessinée", que surgiu devido ao elevado número de publicações que surgiram por volta das décadas dos anos 60 e 70, de bandas desenhadas Franco-Belga. Contudo Zink (1997, p. 4) apresenta outras designações como "Histórias em quadradinhos", "Estorietas", "Fumetti" ou "Graphic novel". 
Apesar das bandas desenhadas serem um universo bastante conhecido em todo o Mundo e de haver algumas incertezas sobre as suas origens, todas as obras publicadas têm um referencial permanente que as unem, independentemente do país e/ou autor que as elaborou. Renard (1981 apud GONÇALVES, 2013, p. 7) menciona que, estas apresentam ao seu leitor uma história, composta por personagens que vivenciam um conjunto de acontecimentos; ambas são apresentadas através de desenhos que podem ou não estar incorporadas com o texto verbal, tendo um "encadeamento de acontecimentos"; e por fim, estas podem ser impressas em papel e/ou suporte digital.

A banda desenhada é uma tipologia de texto que tem interligado entre si "dois elementos comunicacionais" (BONIFÁCIO, 2005, p. 62), neste caso o texto narrativo e pictórico, que permite ao leitor ter uma perspetiva abrangente e realista de todo o acontecimento apresentado na obra. Estes dois elementos permitem que o leitor ao analisar a obra possa ter a perceção mais concreta de todo o acontecimento retratado.

No entanto, não existe unanimidade por parte dos investigadores sobre o significado concreto do conceito de banda desenhada, uma vez que Zink (1997) indica que quando somos solicitados a definir este recurso, não temos a perceção se havemos de o referenciar quanto "à forma ou ao conteúdo, se ao meio, se ao género, se a uma história específica" (ZINK, 1997, p. 12). Solé (2011) exibe uma proposta mais direcionada para o conceito de banda desenhada histórica, onde menciona que este recurso apresenta uma interligação entre "[...] imagem e texto, abordando temas de índole historiográfico refletindo uma visão do seu autor e de uma determinada época" (SOLÉ, 2011, p. 359). Neste sentido, para este género de BD, Rego (2004, p. 42) indica que deverá existir "uma lógica de verdade factual, cronológica e epocal traduzida por uma verosimilhança tão próxima, quanto possível, da realidade ou melhor, da verdade histórica ou, melhor ainda, da memória colectiva".

Apesar das investigações apresentarem vantagens da sua aplicação no ensino, são ainda poucos os estudos, quer nacionais como internacionais, que permitem discutir e apresentar algumas perspetivas sobre o assunto.

Ao nível de estudos internacionais, no Brasil destacam-se os estudos de Fronza (2007, 2012) e Bonifácio (2005), sobre a exploração de bandas desenhadas no ensino brasileiro, uma vez que neste país, as histórias em quadrinhos são bastante utilizadas nos manuais escolares. Fronza (2007) neste seu estudo de mestrado pretendia aferir os conhecimentos históricos apreendidos pelos alunos através da aplicação da banda desenhada histórica. Para isso, o autor elaborou um instrumento de recolha de dados, baseado nas teorias de Rüsen (2001) ao nível das narrativas históricas e de Chaves (2006) nomeadamente sobre a significância histórica, aplicada à construção de narrativas 
realizadas pelos alunos. De acordo com os resultados obtidos das narrativas produzidas pelos alunos, Marcelo Fronza (2007, p. 148) chegou à conclusão que os alunos:

\begin{abstract}
[...] não produziram nenhuma narrativa histórica, mas sim narrativas ficcionais que se utilizavam de ideias substantivas ligadas aos conteúdos históricos escolares; 2) os conceitos substantivos da História já estão presentes nas histórias em quadrinhos que abordam temas históricos e isso fez com que os jovens valorizassem mais as ideias ligadas à memorização do conteúdo e à aprendizagem divertida do que aos conceitos históricos em si; e 3) as histórias em quadrinhos com temas históricos permitiram que os jovens produzissem um conceito de segunda ordem, a competência do narrar.
\end{abstract}

Num outro estudo, realizado no âmbito do doutoramento, Fronza (2012) pretendeu averiguar quais os significados e valores que os jovens estudantes do ensino médio dão às ideias de verdade histórica e de intersubjetividade quando leem histórias em quadrinhos. $O$ autor utilizou alguns excertos de BDs, uma da autoria de Diniz e Eder (2008) e outra de Paiva e Schwarck (1995), onde ambas as obras abordavam a temática da Independência do Brasil. Uma parte do seu estudo consistiu em investigar as construções das bandas desenhadas realizadas pelos alunos, sobre a Independência do Brasil, tendo como orientação os "artefactos culturais apresentados", onde o autor pretendia verificar "como o processo criativo e sua relação com a intersubjetividade e verdade se relacionam com as teorias ligadas à dimensão estética da cultura histórica" (FRONZA, 2012, p. 424).

Com base nos dados obtidos, pela construção das bandas desenhadas dos alunos, o autor conclui que a identidade histórica pode expressar-se de várias formas, podendo ser uma identidade nacional, que exprima "consciência histórica tradicional"; uma identidade nacional onde exista uma mobilização de outras tradições, apresentando assim uma "consciência histórica critica" e/ ou uma identificação coletiva, direcionada para a "história da humanidade" onde expresse o desejo da "liberdade e da igualdade entre os homens através do reconhecimento mútuo dos seus modos de ser e de viver" (FRONZA, 2012, p. 428). Deste modo, o autor afirma que as bandas desenhadas podem "contribuir vivamente para 0 contato desses sujeitos com formas de viver passadas distintas, mas significativas, que forneçam sentido para à sua vida prática contemporânea” (FRONZA, 2012, p. 433).

No estudo de Bonifácio (2005) a autora apresenta como tema da sua dissertação de mestrado "História $\mathrm{e}(\mathrm{m})$ quadradinhos: análise sobre a História ensinada na arte sequencial", em que pretendia apurar a existência do conteúdo histórico nas bandas desenhadas, de modo a verificar a sua pertinência em contexto de sala de aula. Consequentemente, a autora, apresenta um capítulo sobre obras que retratam alguns acontecimentos históricos, nomeadamente a coleção da Turma da Mónica, de Maurício de Sousa, que é uma das personagens brasileiras da BD, mundialmente conhecida. As obras referenciadas, apesar de terem um cunho comercial, integram também uma grande função 
educativa histórica, uma vez que os autores apresentam apontamentos históricos, nomeadamente as caracterizações das personagens, bem como a narração dos factos históricos, porém as histórias aos quadradinhos revelam uma vertente humorística, que torna a exploração mais lúdica. Em modo de conclusão, a autora no que diz respeito à aplicação das bandas desenhadas históricas no ensino da História, afirma que estas podem proporcionar um momento lúdico, estimulativo e criativo nas aulas.

\begin{abstract}
Analisar os quadrinhos, compará-los com outras linguagens, lê-los também de forma prazerosa, produzi-los em sala de aula, individual ou coletivamente, são apenas algumas das inúmeras possibilidades a serem exploradas por meio de sua presença em sala de aula. Tais experiências podem conferir novos contornos e potenciais criativos, atribuindo novos significados às aulas de História (BONIFÀCIO, 2005, p. 198).
\end{abstract}

Os autores brasileiros Santos e Vergueiro (2012) publicam na revista científica Eccos o artigo "Histórias em quadrinhos no processo de aprendizado: da teoria à prática" em que apresentam um conjunto de estratégias que permitem aos professores ter uma visão de como podem explorar e utilizar as bandas desenhadas como um recurso pedagógico em contexto de sala de aula, de forma a conseguir alcançar os seus objetivos, uma vez que no Brasil existe uma prática frequente das histórias em quadradinhos no ensino.

No mesmo ano, Vergueiro e Pigozzi (2012), apresentam um estudo de caso intitulado de "Histórias em quadradinhos como suporte pedagógico: o caso de Watchmen", que tinha como objetivo verificar a riqueza deste recurso, no que diz respeito à articulação dos "códigos escritos e visuais", através do uso da obra do autor britânico Alan Moore. Através deste estudo, os autores, chegaram à conclusão que a aplicação desta obra, na abordagem da teoria do caos e a relação com as conceções sociais de Max Webber, permitem deixar uma panóplia de estratégias pedagógicas, que os professores poderão adotar nos seus contextos, afirmando que:

\footnotetext{
[...] fica mais uma vez comprovado que os professores do Ensino Médio - e também dos demais níveis de ensino - têm, nas histórias em quadrinhos, um importante aliado nas atividades escolares, pois esse recurso informacional possibilita a ampliação do trabalho com os educandos, auxiliando no aprendizado por meio de uma linguagem mais agradável e próxima dos alunos (VERGUEIRO; PIGOZZI, 2012, p. 41).
}

Em Portugal, nas duas últimas décadas, surgem vários estudos relevantes sobre a Banda Desenhada, uns sobre análise de Bandas Desenhadas Históricas (LAMEIRAS; BOLÉO; SANTOS, 1999; REGO, 2004; ZINK, 1997, 1999) e outros da sua aplicação no ensino (FERTUZINHOS, 2004; GONÇALVES, 2013; MOTA, 2012; SOLÉ, 2009, 2011, 2013).

Rui Zink (1997) cuja tese de doutoramento intitulada "Banda Desenhada Portuguesa Contemporânea", publicada em 1999 com o título de "Literatura Gráfica? Banda Desenhada 
Portuguesa Contemporânea", visou aprofundar o estudo desta temática, nomeadamente pesquisar e analisar a banda desenhada portuguesa contemporânea do período de 1968 a 1994, procedendo a uma análise e reflexão exaustiva das mesmas. Deste modo, o autor concluiu que nos dias de hoje muitos são aqueles que questionam a existência ou não da banda desenhada portuguesa, sendo poucas as editoras que apostem nestas obras literárias, porém estas não podem ser culpadas pela escassez de BD portuguesa, pois segundo o autor, existe um grande número de ilustradores de BDs, mas de escritores é quase "nula", e para haver bandas desenhadas é necessário haver em primeiro lugar autores.

Por sua vez, Rego (2004) desenvolveu um estudo de caso, sobre a obra de Relvas "Çufo", o autor analisa esta obra, através de uma metodologia, que permite comentar "trechos, ou aspetos do texto em função de alguns conceitos a explorar" de forma a "entender as estratégias subjacentes à condução da mensagem e os seus contornos, explícitos e implícitos" (REGO, 2004, p. 48). Lameiras, Boléo e Santos (1999) no artigo "A BD e o 25 de Abril: Um outro olhar" publicado na Revista Camões, apresentam ao leitor a relação que a banda desenhada tem com a Revolução de Abril. Os autores ao longo do artigo vão apresentando como a BD aborda este acontecimento histórico, destacando algumas obras portuguesas, como "O País dos Cágados" de Artur Correia e António Almeida, que Boléo afirma como a "principal BD que conta a história do 25 de Abril, incluindo os seus fundamentos, num distanciado tom de sátira pleno de humor" e/ ou como esta ganha uma nova função, a sua utilização como um instrumento pedagógico.

Vários estudos sobre Banda Desenhada foram aplicados em vários níveis de ensino, reforçando as potencialidades pedagógicas deste recurso para o ensino da História. $O$ estudo de Fertuzinhos (2004) sobre "A Aprendizagem da História no 1. Ciclo do Ensino Básico e o uso do Texto Prosa e da Banda Desenhada" aplicado numa turma de 4. ano de escolaridade da cidade de Guimarães, tinha como objetivo verificar, a partir das bandas desenhadas e de textos em prosa, os conhecimentos que os discentes desenvolviam quando os lessem. Segundo o autor, este estudo foi desenvolvido durante a temática da disciplina de Estudo do Meio "A formação de Portugal/ Reinado de D. Afonso Henriques", tendo uma forte ligação com o ensino do Português, criando uma interdisciplinaridade entre elas. Como resultados constatou que os alunos que trabalharam com texto em prosa conseguiram demonstrar o conhecimento que foram adquirindo ao longo do estudo, enquanto o grupo que trabalhou com banda desenhada demonstrou algumas dificuldades, isto porque, segundo o autor, "uma vez que a contextualização e ligação entre os conteúdos não é tão articulada como no Texto Prosa, os alunos têm dificuldade em adquirir uma percepção global da história" (FERTUZINHOS, 2004, p. 281). 
Também com crianças do 1. Ciclo, Solé (2009) desenvolve uma atividade realizada no âmbito do seu doutoramento, cuja designação é "A expansão portuguesa a partir da exploração de uma banda desenhada". Esta atividade foi implementada numa turma de 4.0 ano, com 25 alunos, cujo objetivo era apurar as ideias e os conhecimentos históricos que os alunos do 1. Ciclo constroem a partir da exploração de bandas desenhadas históricas e outras fontes historiográficas. Para recolha de dados, a autora apoiou-se nos diários de aulas e nas narrativas elaboradas pelos alunos, sendo posteriormente criado um conjunto de categorias, para analisar os dados obtidos.

A nível do secundário, apresentamos vários estudos que aplicam este recurso nas áreas disciplinares de História e de Geografia. Assim, o estudo de Mota (2012), " A Banda Desenhada como representação gráfica-verbal na aprendizagem da História e Geografia", foi desenvolvido em duas turmas de 7. ano da Escola Francisco Sanches, nas disciplinas de História com a temática "O Mundo Romano no Apogeu do Império" e em Geografia o "Ambiente e desenvolvimento Sustentável". Com este estudo a autora afirma, que de modo geral, os alunos conseguiram compreender os conteúdos abordados, através da análise das construções das bandas desenhadas que os alunos efetuaram. Gonçalves (2013) desenvolve um estudo referente à "Leitura e interpretação da Banda Desenhada histórica e os desenhos na expressão dos conhecimentos geográficos", em que pretendeu averiguar, na disciplina de História, como os alunos interpretavam as bandas desenhadas e que informação, estes obtêm para desenvolver o seu conhecimento histórico. A partir da análise dos dados recolhidos da aplicação dos instrumentos aos alunos, constatou a autora que os alunos foram evoluindo ao longo da implementação do projeto, em que se verificou um desenvolvimento da capacidade de reflexão, permitindo uma "maior compreensão e aptidão interpretativa".

Destacamos ainda, o estudo do investigador inglês Peter Lee (2001) publicado nas Atas das Primeiras Jornadas Internacionais de Educação Histórica, que teve como finalidade averiguar a conceção dos alunos sobre as narrativas em História, no âmbito do Projeto CHATA aplicado a 320 alunos, com idades compreendidas entre os 6 e os 14 anos de idade. Neste estudo foram aplicadas duas bandas desenhadas, cuja temática retratava a ocupação romana das ilhas Britânicas, mas com perspetivas diferenciadas. Como conclusão do estudo o autor adverte os professores para alguns cuidados que deverão ter ao apresentar várias versões sobre o mesmo assunto, evitar confundir os alunos e levá-los a pensar que estas podem conter erros, mas será antes necessário que estes compreendam que ambas as histórias são válidas mas apontam para sentidos diferenciados, apelando à multiperspetividade em História. Este estudo serviu de modelo para investigações que se realizaram em Portugal, nomeadamente a investigação de Gago (2001) realizada no âmbito 
do mestrado "Concepções de alunos acerca da variância da narrativa histórica", que tinha como objetivo analisar como é que os alunos compreendem a variância da narrativa histórica. Constatou que os alunos apresentam ideias sobre a narrativa histórica e a sua variância em graus mais ou menos elaborados, não estando estas ideias dependentes do nível de escolaridade, pois alunos mais novos podem situar-se em níveis de competência histórica mais elevada, ou vice-versa dependendo da tarefa em si.

Perante esta breve revisão de literatura pelas investigações de autores internacionais e/ou nacionais, sobre o estudo da banda desenhada, podemos apurar que cada vez mais existem investigadores que desenvolvem projetos com o intuito de demonstrar a riqueza que as histórias aos quadradinhos possuem no campo do ensino, realçando o contributo deste recurso/ferramenta didática para o ensino de História.

\title{
Potencialidades da Banda Desenha no Ensino da História
}

No campo do ensino, a potencialidade da Banda Desenhada Histórica como recurso pedagógico ou fonte documental é inquestionável, como o afirma Bonifácio (2005, p. 31):

\begin{abstract}
[...] a importância dos quadradinhos para a História, seja como recurso ou como fonte documental e, principalmente, registra-se a necessidade de atenção e cuidado que o trabalho merece, em função da presença de objetivos distintos entre o saber histórico escolar, que busca a formação e elaboração do conhecimento histórico formal e a linguagem dos quadrinhos, cuja maior finalidade é o entretenimento, ainda que também seja um meio de informação e representação social.
\end{abstract}

Contudo, a aplicação da banda desenhada histórica em contexto de sala de aula, como um recurso pedagógico, não foi sempre bem vista, neste sentido Mota $(2012$, p. 7) afirma que a sua utilização "era vista com desconfiança por parte de educadores e professores, muito pelo seu poder de influência na forma de agir e ser das pessoas". Esta ideia é também reafirmada por Oliveira e Souza (2013) ao asseverarem que existem docentes que acreditam que a sua aplicação no ensino pode trazer consequências prejudiciais ao desenvolvimento intelectual da criança.

Porém, essa visão tem-se vindo a desconstruir, com a realização de vários estudos, como anteriormente apresentamos, que demonstram a pertinência da sua utilização no ensino, sendo que este recurso poderá desenvolver nos alunos várias competências, tomando como exemplo, a visão de Palhares citado por Gonçalves (2013, p. 10) mencionando que as bandas desenhadas apresentam

\footnotetext{
[...] uma dupla função, visto servirem tanto como fonte de pesquisa histórica, quanto um novo recurso onde os estudantes possam interpretar o passado. Essa última possibilidade tem um grande potencial, visto que o passado nem sempre pode ser facilmente ordenado e compreendido pelos alunos. Deste modo, o texto escrito usualmente oferece o estranho passado histórico pode ser compreendido de uma nova forma.
} 
Segundo Fertuzinhos (2004, p. 42) a aplicação deste recurso no ensino é de extrema importância, uma vez que "uma gravura, uma legenda é um método de ensinar a ler que permite ultrapassar as dificuldades com que textos densos brindam as crianças", podendo assim o docente estimular as crianças para o gosta da leitura, uma vez que os alunos ao serem confrontados com textos de extensão densa, cria entre eles um clima de desmotivação para a sua exploração, podendo assim a BD ser um meio facilitador de estes fomentarem o seu conhecimento a partir, da informação histórica patente nas histórias em quadradinhos.

Contudo, Solé (2013) reforça um ponto bastante pertinente no que diz respeito à Banda Desenhada Histórica, mencionando que "é preciso uma adaptação do conteúdo à forma, com o objetivo de criar empatia com o leitor e facilitar o envolvimento na narrativa histórica e nas personagens históricas ou factuais" (SOLÉ, 2013, p. 16). Para criar essa ligação, o docente e o aluno devem ter a noção da gramática da BD (ZINK, 1999), dominar os elementos morfosintáticos, como por exemplo, balão, vinheta, figura, onomatopeia, para assim ter um maior domínio na literacia de Banda Desenhada, pois "a leitura de quadrinhos é complexa e não deve se restringir ao texto ou ao enredo; ler e perceber os recursos da linguagem, da estética e da narrativa das narrativas quadrinizadas amplia as significações que podem ser extraídas de seu conteúdo" (SANTOS; VERGUEIRO, 2012, p. 93).

Segundo Pereira (2013) o docente ao utilizar as "histórias aos quadradinhos" como recurso pedagógico deve ter a perceção do material

[...] autêntico que, pela sua riqueza de vocabulário, onomatopeias, gíria, expressões idiomáticas e símbolos, permite ao aluno aproximar-se um pouco mais de situações comunicativas fora da sala de aula, atuando como estímulo para a aprendizagem destes novos conteúdos (PEREIRA, 2013, p. 35).

Por outro lado, a aplicação deste recurso no ensino da História, segundo Guay e Charrette (2009) citado por Gonçalves (2013, p. 12-13), deve contemplar um conjunto de pressupostos, nomeadamente no desenvolvimento do conhecimento histórico, podendo ser aplicado uma "situação-problema" através do questionamento das ilustrações, que permite aos alunos alcançar a "primeira etapa da abordagem histórica". Seguidamente, os autores defendem que esta aplicação permite que os alunos desenvolvam o pensamento crítico, uma vez que as BDs históricas apresentam uma visão histórica de um autor perante um acontecimento, e por isso essa interpretação pode conter algumas lacunas históricas, devendo os alunos "avaliar a pertinência dos propósitos do autor, numa perspetiva histórica; avaliar a qualidade da representação do objeto histórico apresentado na BD e destacar elementos retirados da ficção".

Neste sentido, o filósofo alemão Rüsen (2016) na "Didática da História", defende que a imagem é um aspeto de aprendizagem histórica, devemos interpretar a sua informação, 
para posteriormente pô-la em prática, estabelecendo metas, de forma a alcançar a aprendizagem histórica, sendo para isso necessário os alunos estarem envolvidos desde o início na abordagem histórica, pois a "aprendizagem histórica precisa ser acessível e significativa para todas as pessoas" (RÜSEN, 2016, p. 26).

Por outro lado, o uso da Banda Desenhada Histórica pode ser um recurso enriquecedor na construção de conhecimento histórico por parte dos alunos, podendo ser aplicado no ensino de várias maneiras, conforme Vilela (2004) citado por Santos e Vergueiro (2012, p. 91) sustenta ao afirmar que esta pode contribuir para "ilustrar ou fornecer uma ideia de aspectos da vida social de comunidades do passado; como registros da época em que foram produzidos e como ponto de partida de discussões de conceitos da História".

Sendo a Banda Desenhada uma narrativa sequencial, existe um conjunto de aspetos que são fundamentais, para que uma narrativa histórica seja considerada de eleição, ao nível do seu "caracter descritivo-explicativo", como sustenta Atkison (1978) citado por Barca e Gago (2004, p. 33), devendo integrar "variedade de factores selecionados, pluralidade de causas, particularidade de alguns factores, importância relativa de causas e distinção entre causas de longa duração e imediatas".

Solé (2011) afirma que a Banda Desenhada Histórica permite que os alunos construam e desenvolvam o seu conhecimento histórico, devido a um conjunto de fatores que a banda desenhada propícia, nomeadamente:

\begin{abstract}
A riqueza dos desenhos com detalhes históricos e geográficos podem ser trabalhos na sala de aula (ao nível do vestuário, adereços, transportes, espaços diversos); A conjugação do texto com a imagem é um elemento facilitador na linguagem e por consequência na aquisição do conhecimento histórico; Permitem comparar factos históricos narrados na BD com posteriores pesquisas realizadas para aprofundamento de determinados conteúdos; Contribuem para a aquisição de conteúdos históricos e a aquisição de conceitos substantivos de uma forma lúdica, motivando-os para a aprendizagem da História, principalmente nos mais novos; Proporcionar o desenvolvimento de conceitos de segunda ordem como o tempo, mudança, explicação histórica, causalidade, significância e empatia histórica; Em suma, contribuem para despertar o interesse pela disciplina de História e Geografia (SOLÉ, 2011, p. 369-370).
\end{abstract}

Mas é preciso ter alguns cuidados na hora da escolha da obra a ser trabalhada para um determinado conteúdo histórico, pois deve-se ter em atenção vários aspetos, nomeadamente o rigor científico ao nível do conteúdo histórico transmitido, os objetivos que se pretende alcançar, o ano de escolaridade e o conteúdo/tema a ser trabalhado (SOLÉ, 2013). Isto porque, uma vez que a banda desenhada é um meio de comunicação para massas, estas por vezes podem ser manuseadas, podendo estes serem "instrumentos de manipulação ideológica, ajudando a criar uma visão histórica que, muitas vezes, ultrapassa o conteúdo do documento histórico" (BARBOSA, 2006 apud SOLÉ, 2013, p. 370). Existe um conjunto de medidas e de atenções a ter na aplicação deste recurso em contexto escolar, 
pois estas obras sofrem um conjunto de interferências, quer por parte dos seus autores, quer das suas editoras, o que exige uma maior atenção do docente para averiguar a veracidade histórica daquela obra e se esta se encontra adequada para o nível de ensino que se pretende aplicar (SOLÉ, 2013).

\section{Metodologia}

Este estudo, de natureza qualitativo interpretativo (ERICKSON, 1986), foi desenvolvido tendo por base a metodologia de investigação-ação (COUTINHO et al., 2009), numa abordagem construtivista da aprendizagem (FOSNOT, 1996, p. 53), "teoria psicológica pós estruturalista, que constrói a aprendizagem como um processo de construção interpretativo e recursivo por parte dos alunos em interação com o mundo físico e social", ou seja, desejou-se que as crianças pudessem alcançar e lou aprimorar os seus conhecimentos, tendo por base a filosofia construtivista.

Nesta perspetiva, o presente estudo desenvolveu-se segundo o modelo de aula oficina (BARCA, 2004), que se fundamenta no sócio construtivismo, em que os alunos têm um papel na sua formação demonstrando as suas conceções prévias e experiências, enquanto o papel do docente centra-se numa perspetiva investigativa, ao nível social, apresentando um conjunto de atividades problematizantes.

\section{Objetivos e questões de investigação}

O estudo teve como objetivo principal averiguar as potencialidades da Banda Desenhada como recurso didático e fonte historiográfica no ensino da História. Para a concretização deste objetivo formularam-se uma série de objetivos específicos a ser alcançados pelos alunos:

a) Promover o gosto pela leitura da Banda Desenhada histórica;

b) Explorar conteúdo histórico a partir da Banda Desenhada histórica;

c) Desenvolver o pensamento histórico e o espírito crítico cruzando informação da BD com outras fontes históricas e historiográficas;

d) Fortalecer a construção do conhecimento do ensino da História aplicando a BD;

e) Promover um espírito cooperativo e autónomo entre os alunos.

Neste sentido, o estudo pretendeu responder às seguintes questões de investigação:

1. "Que conhecimento histórico os alunos extraem de uma Banda Desenhada?"

2. "Que conhecimento histórico os alunos aplicam na construção de uma Banda Desenhada?" 


\section{Participantes}

O estudo foi implementado durante o estágio de prática Educativa Supervisionada,

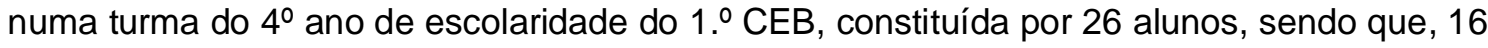
eram rapazes e 10 eram raparigas, com idade entre os 9 e os 10 anos, numa escola urbana do Norte de Portugal. Ao nível socioeconómico e cultural a turma pertencia a famílias com um nível socioeconómico médio/alto. O aproveitamento escolar era bastante satisfatório. Observou-se que alguns dos alunos da turma, nos intervalos das aulas, ocupavam parte deste, mostrando aos colegas os álbuns de BD que estavam a ler, o que fez com que viesse a despertar a curiosidade dos outros alunos para este tipo de texto. Esta situação motivounos para implementar como projeto investigativo, a abordagem da BD como recurso pedagógico para o ensino da História.

\section{Procedimentos e instrumentos de recolha de dados}

Com base na perspetiva construtivista, foi elaborado um conjunto de estratégias pedagógicas, que fossem adequadas ao projeto e às características que a amostra continha. Deste modo, ao longo do projeto, os alunos realizaram um conjunto de atividades, como por exemplo, exploração de bandas desenhadas históricas, especialmente alguns excertos do álbum "A Grande Aventura: por mares nunca antes navegados " dos autores portugueses A. C. Reis e J. Garcês (1992) e " O Achamento do Brasil- A Carta de Pero Vaz de Caminha a El-Rei D. Manuel " dos autores brasileiros H. Simões e R. Gonzaga (2000) fichas de interpretação e de comparação das BDs, visualização de vídeos históricos, exploração de fontes documentais, construção de bandas desenhadas e, por fim, uma visita de estudo ao Museu interativo e Parque temático "World of Discoveries", situado na cidade do Porto.

É importante atendermos ao contexto de produção das duas obras para identificarmos diferenças existentes a vários níveis. A Grande Aventura: por mares nunca antes navegados" dos autores portugueses A. C. Reis e J. Garcês (1992) é uma obra que faz parte de uma coleção de quatro títulos subordinados a determinados períodos históricos, a saber: A Pátria Lusitânia (1. a edição de 1987); A Grande Aventura (1. e edição 1986); A Restauração da Independência (1. a edição de 1988); A Revolução da Liberdade (1. a edição de 1989) que posteriormente foram compilados numa só edição: A. C. Reis e J. Garcês (2007). A História de Portugal em Banda Desenhada. Rio Tinto: Edições ASA. A obra espelha grande rigor histórico, quer ao nível de conteúdo pelo trabalho apurado realizado por António do Carmo Reis, investigador e especialista em História Moderna e Contemporânea, quer pelos desenhos realizadas por José Garcês, sobejamente 
reconhecido como um dos maiores ilustradores de banda desenhada em Portugal. A obra dedica apenas 2 páginas à problemática da chegada de Pedro Álvares Cabral ao Brasil, o relato deste feito pelo secretário Pero Vaz de Caminha, que descreve o acontecimento a nível factual, com marcadores temporais e espaciais bem vincados (o dia da chegada-2 de abril, o monte pascoal na terra de Vera Cruz), a descrição dos indígenas, (alvoraçados, pacíficos, assustados mas também intrigados com os portugueses) representados em termos pictóricos com traço mais estilizado.

A outra obra de H. Simões e R. Gonzaga, "O Achamento do Brasil - A Carta de Pero Vaz de Caminha a El-Rei D Manuel”. Ilhéus-Bahia, de 2001, pp. 7-32, reflete o rigor historiográfico imposto pelo especialista em História dos descobrimentos Henrique Simões, que se baseia na Carta de Pero Vaz de Caminha, desenhos pormenorizados e de rigor estético de Reinaldo Gonzaga, representando os indígenas com pinturas e adereços bem detalhados, corpos robustos e bem constituídos sobressaindo a nudez dos indígenas, a estranheza dos portugueses, misturada com alguma maledicência de algumas cenas dos marinheiros para com as nativas, incorporando outras leituras para além do textual ou ilustrativo da informação veiculada pela obra de Pero Vaz de Caminha.

O estudo foi realizado em dois grandes momentos, numa primeira estância desejavase apurar os conhecimentos que os alunos adquiriam, através da exploração de bandas desenhadas históricas, e numa segunda fase, que conhecimento histórico aplicavam na construção das suas próprias bandas desenhadas. Este projeto foi executado, em cinco sessões, na área de Estudo do Meio, na abordagem da "Expansão marítima portuguesa", que é um dos tópicos programáticos do ensino da História, para este ano de escolaridade em Portugal. 
Figura 1 - Excerto da obra: "A grande aventura..." de A. C. Reis e J. Garcês (1990, p. 56).

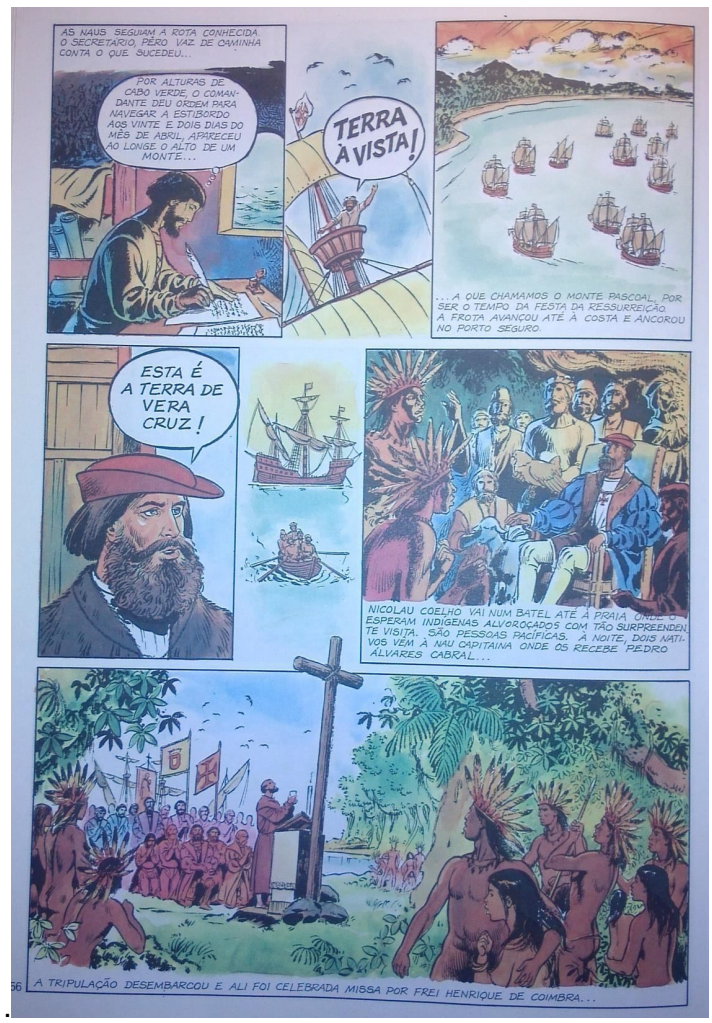

Figura 2 - Excerto da obra "O Achamento do Brasil - A Carta de Pero Vaz de Caminha a El-Rei D Manuel" dos autores H. Simões e R. Gonzaga (2000, p. 12).

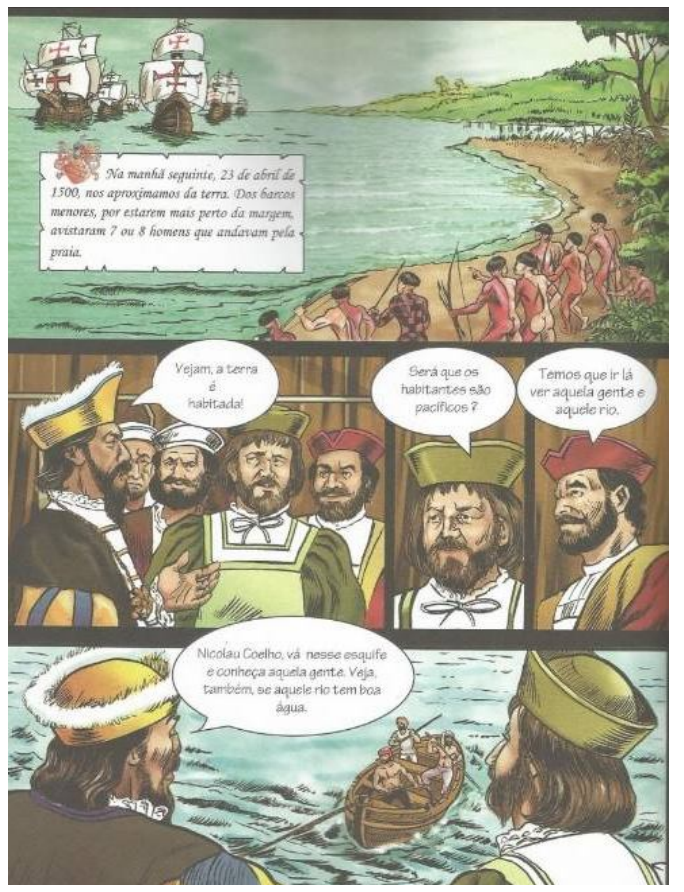

A primeira sessão teve uma interdisciplinaridade com o ensino do Português, porque segundo os documentos oficiais, a banda desenhada é um dos tópicos a serem trabalhados com os alunos no $4 .^{\circ}$ ano. Por isso, para além da abordagem histórica e curiosidades sobre esta tipologia de texto, foi apresentado uma ficha de levantamento de ideias sobre as "histórias aos quadradinhos".

Na segunda sessão do projeto, abordou-se os conteúdos históricos da "Conquista de Ceuta" e a "Descoberta dos Arquipélagos dos Açores e Madeira". Para além de vários recursos aplicados, foram explorados alguns excertos da banda desenhada "A Grande Aventura" de Reis e Garcês, e depois uma "ficha de interpretação" sobre os excertos explorados.

$\mathrm{Na}$ terceira sessão realizou-se a visita de estudo ao Museu interativo e Parque temático "World of Discoveries", situado na cidade do Porto.

$\mathrm{Na}$ quarta sessão, a temática explorada foi sobre a "descoberta" do Brasil, em que os alunos tiveram a oportunidade de ter contacto com vários materiais históricos, como o "Mapa Terra Brasilis", atribuído a Lopo Homem e Renéis de 1519, excertos das bandas desenhadas "A Grande Aventura" dos autores Reis e Garcês (1992) e "O Achamento do 
Brasil - A Carta de Pero Vaz de Caminha a El-Rei D Manuel" de Simões e Gonzaga (2000); a biografia de Pedro Alvares Cabral, excertos da carta de Pero Vaz de Caminha a el-rei D. Manuel, tendo sido aplicado alguns instrumentos de recolha de dados, como a ficha de interpretação e de comparação das obras exploradas (instrumento 1 e 2).

Numa primeira estância, os alunos foram confrontados com o mapa, anteriormente referenciado, criando um momento de diálogo levantando algumas questões, que permitissem analisar a fonte histórica. Posteriormente, a turma analisou um excerto da obra "A Grande Aventura", que retratava a descoberta do Brasil, onde no final da sua exploração foi aplicado uma ficha de interpretação (instrumento 1), cujo intuito era averiguar a interpretação dos alunos sobre a obra apresentada.

Após a realização desta tarefa, os alunos tiveram a oportunidade de explorar a biografia de Pedro Alvares Cabral e os excertos da carta de Pero Vaz de Caminha, que permitiram enriquecer as competências de recolha de informação dos nossos alunos a partir das diversas fontes históricas apresentadas.

Por fim, apresentou-se aos alunos alguns excertos da obra brasileira "O Achamento do Brasil - A Carta de Pero Vaz de Caminho a El- Rei D. Manuel", onde se desejava que os nossos alunos tivessem a oportunidade de averiguar a perspetiva histórica, por parte dos autores brasileiros, para posteriormente puderem realizar a tarefa de comparar as duas Bandas Desenhadas através de uma ficha de comparação (instrumento 2), demonstrando as diferenças e semelhanças que as obras exploradas continham sobre a mesma temática histórica, quer ao nível do texto verbal como do texto pictórico.

No segundo momento deste projeto, na quinta sessão, os alunos construíram as suas bandas desenhadas sobre a "descoberta" do Brasil (instrumento 3). Esta dinâmica tinha como finalidade averiguar os conhecimentos adquiridos ao longo da abordagem desta temática e, por outro lado, perceber quais as fontes que estariam a ser retratadas na elaboração das suas obras. De salientar que os alunos tiveram total liberdade para construir as suas bandas desenhadas, mas sem qualquer contacto com fontes históricas durante a sua elaboração, pois pretendia-se averiguar como aplicavam o conhecimento adquirido e quais as fontes em que se baseavam para a sua construção.

\section{Análise e discussão de alguns dados}

Neste momento serão apresentados alguns dados obtidos, a partir dos instrumentos aplicados no projeto para a recolha de dados. Numa primeira parte apresentam-se os dados da "Ficha das Comparações" (instrumento 2), que tinha como objetivo averiguar as perspetivas dos alunos, no que diz respeito às semelhanças e/ou diferenças das bandas 
desenhadas, "A Grande Aventura" de Reis e Garcês (1992) e "O Achamento do Brasil- A Carta de Pero Vaz de Caminha a El-Rei D. Manuel" de Simões e Gonzaga (2000). Este instrumento de recolha de dados estava direcionado para a primeira questão de investigação do projeto: "Que conhecimento histórico os alunos extraem de uma Banda Desenhada?".

Os dados recolhidos das respostas dos alunos foram analisados de forma indutiva inspirados na Grounded Theory (CORBIN; STRAUSS, 2008), o que permitiu construir um sistema de categorização, com os respetivos descritores.

Tabela 1 - Sistema de categorização (categorias e descritores) das semelhanças e diferenças das BDs segundo as respostas dos alunos do 1. Ciclo

\begin{tabular}{|c|c|c|c|}
\hline \multirow[b]{2}{*}{ Categorias } & \multirow[b]{2}{*}{ Descritores } & \multicolumn{2}{|c|}{ Ocorrências } \\
\hline & & $\begin{array}{l}\text { Semelhanças } \\
\qquad(N=26)\end{array}$ & $\begin{array}{l}\text { Diferenças } \\
\qquad(\mathrm{N}=26)\end{array}$ \\
\hline Temática & $\begin{array}{l}\text { Resposta em que os alunos mencionam semelhanças } \\
\text { ou diferenças nas bandas desenhadas no que diz } \\
\text { respeito à temática que está retratada nas obras. }\end{array}$ & 14 & 1 \\
\hline Ilustração & $\begin{array}{c}\text { Resposta em que os alunos mencionam semelhanças } \\
\text { ou diferenças nas bandas desenhadas no que diz } \\
\text { respeito às ilustrações nas obras. }\end{array}$ & 1 & 20 \\
\hline Religioso & $\begin{array}{c}\text { Resposta em que os alunos mencionam semelhanças } \\
\text { ou diferenças nas bandas desenhadas no que diz } \\
\text { respeito às cerimónias religiosas celebradas por Frei } \\
\text { Henrique. }\end{array}$ & 17 & 12 \\
\hline Personagens & $\begin{array}{c}\text { Resposta em que os alunos mencionam semelhanças } \\
\text { ou diferenças nas bandas desenhadas no que diz } \\
\text { respeito às personagens que se destacaram no } \\
\text { acontecimento histórico (Pedro Álvares Cabral, Frei } \\
\text { Henrique de Coimbra, Vasco de Ataíde) }\end{array}$ & 3 & 0 \\
\hline Embarcações & $\begin{array}{c}\text { Resposta em que os alunos mencionam semelhanças } \\
\text { ou diferenças nas bandas desenhadas no que diz } \\
\text { respeito às embarcações utilizadas pelos navegadores } \\
\text { (naus, caravelas, navio, batel) }\end{array}$ & 12 & 0 \\
\hline $\begin{array}{c}\text { Caraterização } \\
\text { dos nativos }\end{array}$ & $\begin{array}{l}\text { Resposta em que os alunos mencionam semelhanças } \\
\text { ou diferenças nas bandas desenhadas no que diz } \\
\text { respeito à caraterização dos nativos em termos físicos e } \\
\text { ao nível dos adereços (penas, lanças, pinturas, tanga) }\end{array}$ & 15 & 2 \\
\hline $\begin{array}{l}\text { Conteúdo } \\
\text { histórico }\end{array}$ & $\begin{array}{l}\text { Resposta em que os alunos mencionam semelhanças } \\
\text { ou diferenças nas bandas desenhadas no que diz } \\
\text { respeito ao conteúdo histórico que se encontra patente } \\
\text { nas duas obras exploradas. }\end{array}$ & 4 & 14 \\
\hline
\end{tabular}

Fonte: Elaboração própria. 
Na primeira categoria subordinada à Temática, houve um conjunto de alunos $(n=14)$ que referenciaram que ambas as obras apresentadas abordavam a "descoberta" do Brasil. Porém, apesar de esta identificação ser bastante clara e restrita a este acontecimento, houve alunos que não apresentaram quaisquer semelhanças ou a indicaram.

A segunda categoria llustração mostra que a maioria dos alunos da turma $(n=20)$ achou que as obras analisadas apresentam várias diferenças ao nível da ilustração. Apesar de ambas as obras relatarem o mesmo acontecimento histórico, cada ilustrador interpretou a informação histórica e realizou a sua construção da BD de maneira diferente, consoante a sua filosofia e as fontes historiográficas que usou. Os alunos foram capazes de, através das ilustrações, identificarem diferenças culturais e ideológicas entre o olhar português e o olhar brasileiro no processo de colonização. Reconhecem que na versão portuguesa, os portugueses causaram estranheza junto dos indígenas, que se revelaram submissos, enquanto que na versão brasileira, a presença de armas na recetividade dos portugueses demonstra algum receio da presença destes povos no seu meio. Todavia, "O Achamento do Brasil - A Carta de Pero Vaz de Caminho a El- Rei D. Manuel", foi o álbum que os alunos mais gostaram ao nível das suas ilustrações, porque estas apresentavam maior realismo deste acontecimento histórico, ao nível do vestuário, das embarcações, da vegetação, entre outros aspetos históricos.

A categoria Religioso foi uma das semelhanças e diferenças que os alunos destacaram nas duas obras exploradas, nomeadamente nas celebrações religiosas celebradas pelo Frei Henrique em território brasileiro. Neste modo, no que diz respeito às semelhanças das obras, os alunos apresentam uma tipologia de resposta pouco concisa, tendo como exemplo os alunos A15 e A24, que indicam que ambos os álbuns apresentam a "Missa do Frei Henrique"; "Ambas têm missas.". Contudo, há alunos que apresentam uma visão diferenciada, no que diz respeito a esta categoria, uma vez que durante a análise das histórias aos quadradinhos verificamos que os autores brasileiros referenciaram as duas celebrações religiosas do Frei Henrique, enquanto os autores portugueses só fizeram menção a uma celebração, onde nativos e navegadores participaram em conjunto. Deste modo, os alunos destacam a diferença nas opções realizadas pelos ilustradores, expressa nos seguintes exemplos: (A5) "A cerimónia é celebrada de maneira diferente." (A10) "Numa foram duas missas e no outro só foi uma".

Das sete categorias em análise, a categoria Personagens, que integravam os sujeitos históricos ao nível das personalidades históricas (navegadores, missionários, reis...) foi a menos expressiva, apenas três alunos referiram semelhanças nas duas obras, relativamente à menção dos navegadores Pedro Álvares Cabral e Vasco d'Ataíde e do Frei Henrique. 
Em relação à categoria Embarcações, não teve qualquer diferenciação nas duas obras. Contudo, houve alguns alunos $(n=12)$ que referenciaram semelhanças no tipo de embarcação que os navegadores portugueses utilizaram, nesta expedição que culminou na descoberta do Brasil. Todavia, a tipologia de embarcação utilizada naquela viagem não reuniu unanimidade, como expressamos seguintes exemplos: (A8) "Os barcos."; (A21) "Nas duas têm caravelas portuguesas e naus portuguesas".

Os adereços e pinturas dos nativos, também eles sujeitos históricos representados nas BDs, originou que houvesse uma categoria de análise, designada como Categorização dos nativos, por acharmos que não fazia sentido integrá-lo na categoria personagens, porque se pretendia analisar como os alunos identificavam as diferentes formas de os representarem nas duas versões. Um conjunto de quinze alunos demonstrou que existiam igualdades, ao nível da ilustração dos nativos, nos excertos explorados, particularmente na representação do nu dos nativos. Surgem visões diferenciadas em relação aos adereços que os nativos usavam nas ilustrações das duas obras: o A16 mencionada que "Numa os índios têm chapéus de penas e nos outros estão pintados" e o A14 apresenta a mesma ideia que o colega anterior, "Numa os índios estão pintados e na outra têm penas na cabeça". Parece-nos que a obra brasileira representa os indígenas à semelhança destes povos ameríndios na atualidade, o que poderá sugerir uma visão antropológica na representação de como seriam estes povos no passado.

Por último, na categoria relativo ao Conteúdo histórico, os alunos demonstram que existe uma grande diferenciação no conteúdo histórico, entre as duas histórias aos quadradinhos. O aluno A25 menciona que "A grande Aventura" não indica datas; "O achamento do Brasil" retrata o que aconteceu na nau capitaina durante a visita dos índios". O aluno A19 refere que "O primeiro texto não tem o domingo de Pascoela; O primeiro texto não aparece que Vasco de Ataíde desapareceu; O primeiro texto, os índios não provaram a comida portuguesa". Neste sentido, podemos verificar que, estas diferenças no conteúdo histórico remetem para a quantidade de informação histórica que as obras apresentam e para os marcadores temporais. Neste sentido, as autoras Barca e Gago (2004) mencionam que estas "diferenciações" do conteúdo histórico surgem das visões que cada autor tem sobre o acontecimento em estudo, podendo levantar algumas opiniões contraditórias. Por outro lado, Barbosa (2006 apud SOLÉ 2003) aponta que as bandas desenhadas são uma narrativa de massas e para isso o conteúdo histórico pode sofrer algumas alterações, devido a fatores que ultrapassam, por vezes, os autores. É preciso ressalvar que diferentes perspetivas sobre o conteúdo histórico expresso nas narrativas históricas, historiográficas e estéticas, como é o caso das BDs, são uma construção social situada em um determinado tempo e espaço. Isto é bem visível nas duas obras de BD exploradas pelos alunos, não 
apenas no que é referido, como é referido, o que é valorizado e significativo, mas também no que surge omisso em termos de acontecimentos históricos. A própria terminologia usada, como por exemplo o uso da palavra "achamento" na versão brasileira, enquanto que na versão portuguesa sobressaí a expressão "terra à vista" no sentido de descoberta. Esta dicotomia na própria designação sobre a chegada dos portuguesas a Terra de Vera Cruz, reflete a multiperspectividade e pontos de vista diferentes, entre a perspetiva brasileira que reforça a ideia de achamento (de algo que é achado que até ai era desconhecido), no sentido de chegada a uma nova terra que era desconhecida para os ocidentais, por sua vez, na perspetiva portuguesa, e no contexto da "expansão e dos descobrimentos portugueses", a historiografia tradicional portuguesa utilizam o termo "descoberta" do Brasil, expressão que começa a ser posta em causa pela historiografia mais recente ${ }^{3}$. Esta problemática mantémse bastante candente entre historiadores portugueses da atualidade, manifestada mesmo sobre o nome a atribuir ao museu projetado das viagens portuguesas, em que uns defendem a designação de "Museu das Descobertas" outros "Museu da interculturalidade" ou outras propostas ainda. Os opositores a esta proposta inicial de "Museu das Descobertas" refutam-na classificando de "obsoleto, incorreto e cheio de significados errados". Parece que está previsto chamar-se agora o Museu "A viagem"4.

A tarefa subordinada à construção das bandas desenhadas, idealizadas pelos alunos 1. Ciclo, sobre a "descoberta" do Brasil (instrumento 3), contribuiu para responder à segunda questão de investigação "Que conhecimento histórico os alunos aplicam na construção de uma Banda Desenhada?". Através desta tarefa, pretendeu-se aferir a aplicação do conhecimento histórico dos alunos na elaboração da banda desenhada, tendo como influências as bandas desenhadas exploradas na sessão 4, e o cruzamento de informação a partir de fontes historiográficas ou até mesmo da visita de estudo. De referir, que apenas 23 alunos efetuaram a construção da BD. Esta atividade teve um distanciamento das sessões anteriores de uma semana e os alunos não tiveram qualquer suporte escrito ou digital para realizar as suas bandas desenhadas.

3 Sobre o assunto veja-se: PIMENTA, Alfredo. O Descobrimento do Brasil" Estudos Históricos- XX. Livraria Portugália, Lisboa, 1942. MONTEIRO, N. G. (2010). Idade Moderna: as expansões portuguesas: configurações e conflitos. In RAMOS, Rui (Coord.). A História de Portugal. Lisboa: A Esfera dos Livros, p. 215, 2010. Nuno Monteiro sobre a viagem de Pedro Alvares Cabral escreve: "No facto o que tornariam memorável esta viagem foi a acostagem na América do Sul, em Maio de 1500. Infindáveis são os escritos que procuram conferir intencionalidade à rota seguida, a qual retomou a de Vasco da Gama, mas desviando-se apenas um pouco para oeste. Outros insistem na plausibilidade de outros navegadores portugueses terem antes de Cabral tocado terra na América do Sul. Para todos os efeitos, no entanto, um navio capitaneado por Pêro Vaz de Caminha, imputado autor da celebérrima carta sobre o achamento da nova terra, dita de Santa Cruz, foi enviado para Lisboa para anunciar a boa notícia da descoberta de novos territórios, que a Coroa portuguesa não deixaria de reivindicar.

4 Disponível em: https://observador.pt/2018/09/18/polemica-sobre-o-museu-das-descobertas-ja-chegou-ao-the-guardian/. Acesso em: 13 dez. 2018.

ANTíTESES, v. 11, n. 22, p.635-660, jul./dez. 2018 
Figura 3 - BD do aluno A1

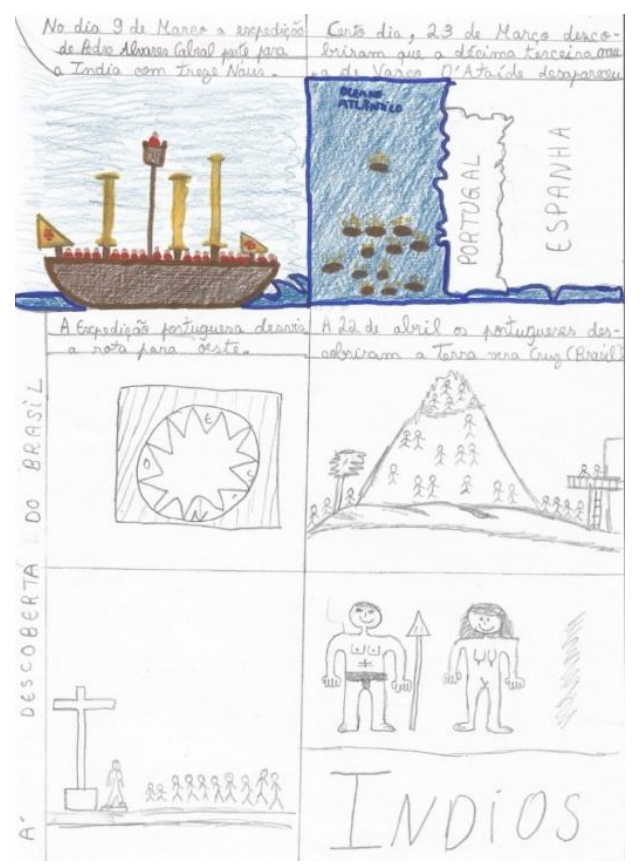

Figura 4 - BD do aluno A4

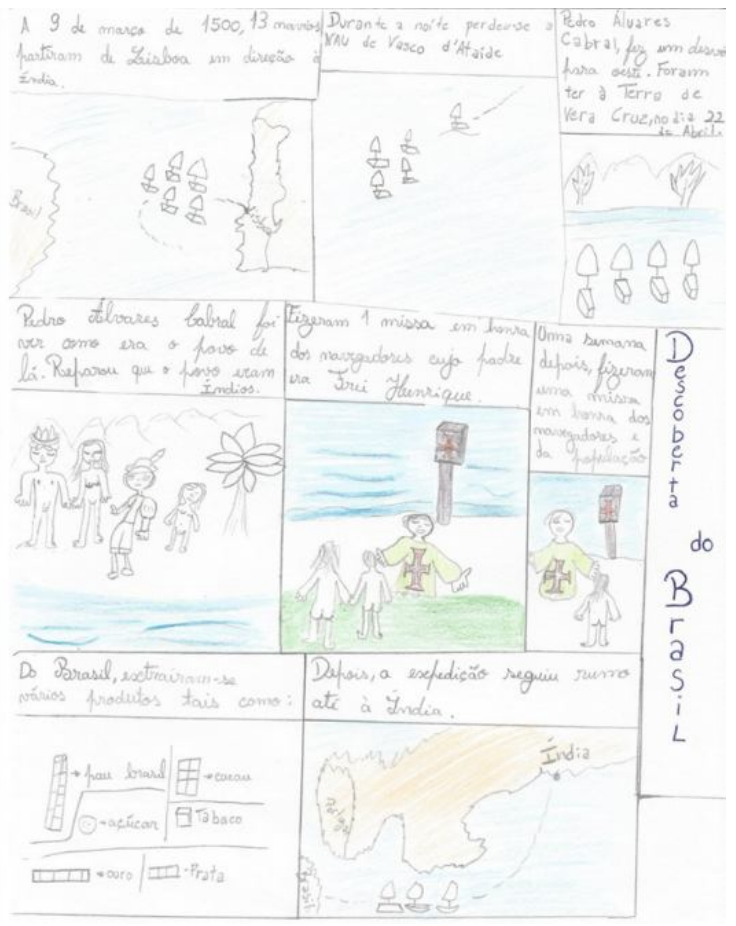

O sistema de categorização que se apresenta (Tabela 2) teve por base os estudos de Fronza (2007) e Mota (2012).

Tabela 2 - Sistema de categorização (categorias e descritores) dos elementos verbais e pictóricos das BDs dos alunos do 1. Ciclo.

\begin{tabular}{|c|c|c|c|}
\hline \multirow[b]{2}{*}{ Categorias } & \multirow[b]{2}{*}{ Descritores } & \multicolumn{2}{|c|}{ Ocorrências } \\
\hline & & $\begin{array}{l}\text { BD- Texto } \\
\text { Verbal } \\
(\mathrm{n}=23)\end{array}$ & $\begin{array}{l}\text { BD- Texto } \\
\text { Pictórico } \\
(\mathrm{n}=23)\end{array}$ \\
\hline Espacial & $\begin{array}{c}\text { Textos verbais e pictóricos que permitem identificar no } \\
\text { espaço a ação do acontecimento histórico (Terra de } \\
\text { Vera Cruz, Monte Pascoal, Índia). }\end{array}$ & 22 & 22 \\
\hline Temporal & $\begin{array}{l}\text { Textos verbais e pictóricos que permitem identificar no } \\
\text { tempo a ação do acontecimento histórico (9 de marco } \\
\text { de } 1500,22 \text { e } 24 \text { de abril, festa da ressurreição). }\end{array}$ & 16 & 2 \\
\hline Religioso & $\begin{array}{c}\text { Textos verbais e pictóricos que permitem identificar as } \\
\text { cerimónias religiosas celebradas por Frei Henrique e } \\
\text { elementos simbólicos do cristianismo (cruz, altar, } \\
\text { cálice, vela e padrão). }\end{array}$ & 15 & 17 \\
\hline Personagens & $\begin{array}{c}\text { Textos verbais e pictóricos que permitem identificar as } \\
\text { personagens que se destacaram no acontecimento } \\
\text { histórico (Pedro Álvares Cabral, Frei Henrique de } \\
\text { Coimbra, Vasco de Ataíde) }\end{array}$ & 18 & 6 \\
\hline Embarcações & $\begin{array}{c}\text { Textos verbais e pictóricos que permitem identificar as } \\
\text { embarcações utilizadas pelos navegadores (naus, } \\
\text { caravelas, navio, batel) }\end{array}$ & 17 & 23 \\
\hline
\end{tabular}




\begin{tabular}{|c|c|c|c|}
\hline $\begin{array}{c}\text { Caraterização } \\
\text { dos nativos }\end{array}$ & $\begin{array}{c}\text { Textos verbais e pictóricos que permitem caraterizar } \\
\text { os nativos em termos físicos e ao nível dos adereços } \\
\text { (penas, lanças, pinturas, tanga) }\end{array}$ & 2 & 20 \\
\hline Vegetação & $\begin{array}{c}\text { Textos verbais e pictóricos que permitem identificar a } \\
\text { vegetação existente na Terra de Vera Cruz } \\
\text { (Coqueiros, outras árvores como palmeiras e o monte) }\end{array}$ & 0 & 12 \\
\hline Produtos & $\begin{array}{c}\text { Textos verbais e icónicos que permitem identificar os } \\
\text { produtos que os navegadores portugueses trouxeram } \\
\text { do Brasil (pau-brasil, açúcar, ouro e prata, tabaco, } \\
\text { cacau). }\end{array}$ & 2 & 2 \\
\hline
\end{tabular}

Fonte: Elaboração própria.

Em análise a todas as bandas desenhadas produzidas pelos alunos, podemos averiguar que na categoria espacial, todos os alunos, exceto um, conseguiram retratar, explicitar e localizar espacialmente de forma legível, os acontecimentos que foram surgindo na expedição de Pedro Álvares Cabral à Índia. Deste modo, todos situaram Lisboa, como ponto de partida da expedição portuguesa até à chegada ao Brasil, durante a semana da Páscoa. Neste tópico, só o aluno A14 mencionou que os navegadores portugueses seguiram o seu "rumo até à Índia".

Ao nível da temporalidade, na categoria temporal, podemos afirmar que a maioria dos alunos teve uma grande preocupação em apresentar nas suas bandas desenhadas marcadores temporais (datas, celebrações como a da Páscoa), o que evidência esta preocupação em datar os acontecimentos e relatá-los por ordem cronológica, que se revela fundamental para compreensão histórica. Contatou-se que a datação dos acontecimentos expressa nas BDs dos alunos revela a forte influência que a banda desenhada "O Achamento do Brasil - A Carta de Pero Vaz de Caminha a El-Rei D Manuel" dos autores Simões e Gonzaga teve nas suas produções, reproduzindo muito dos dados cronológicos que esta apresenta. Perante isto, foram diversas as formas como os alunos indicaram cronologicamente os acontecimentos. Vejamos o exemplo do aluno A5 que legendou na vinheta 1 "A 9 de março de 1500 partiu de Lisboa no objetivo de ir à Índia 13 navios", na vinheta 3 refere "No dia 22 de abril descobriram o Brasil (terra de Vera Cruz)."

Outro ponto de análise nas bandas desenhadas dos alunos prende-se com o marcador da religião/catolicismo expresso na categoria religioso, que integra não só as cerimónias litúrgicas celebradas pelo Frei Henrique de Coimbra, mas toda os elementos simbólicos associados à doutrina cristã, como seja a cruz, o altar, o padrão, o sacerdote. Nesta categoria os alunos demonstraram algumas lacunas, uma vez que na exploração das obras, estes puderam aferir que a segunda celebração do Frei Henrique, teve apenas um altar de madeira, elaborado e transportado pelos navegadores e nativos. Porém, muitas bandas desenhadas dos alunos apresentavam o padrão dos descobrimentos, como o símbolo dessa celebração, 
bem como os cálices e as hóstias que são símbolos da doutrina cristã, que não estavam referenciados, nem ilustrados nas obras exploradas.

No que diz respeito à categoria personagens, os alunos demonstraram grandes dificuldades na representação pictórica das personalidades relacionadas com o acontecimento histórico. A maioria das ilustrações têm uma forte ligação com o texto verbal, ajudando o leitor a perceber qual a intenção da mensagem que o aluno queria transmitir. No geral, os alunos mencionam apenas três personalidades históricas, Pedro Álvares Cabral, Frei Henrique de Coimbra e Vasco d'Ataíde, navegador português que "no dia 23 de março perdeu-se" durante a expedição, conforme o aluno $\mathrm{A} 9$ apresentou na sua BD.

Relativamente à categoria embarcações é possível concluir que todos os alunos ilustraram as embarcações que os navegadores portugueses utilizaram na altura da expedição, contudo essa representação não é uniforme, nem muito fidedigna, pois existem representações das embarcações que possuem na sua maioria apenas uma vela e, por sua vez, a apresentação da dimensão das embarcações é bastante diversificada em todas as propostas dos alunos. Contudo, ao nível verbal, apenas dezassete alunos fazem referência à tipologia de embarcação utilizada pelos portugueses. O aluno A26 tentou ilustrar o interior da embarcação. Esta ilustração tem por base a visita de estudo ao museu interativo e parque temático "World of Discoveries".

No que diz respeito à categoria caraterização dos nativos, ao nível das ocorrências em texto verbal, apenas dois alunos referenciam as diferenças dos nativos em relação aos navegadores portugueses. A caracterização dos nativos é muito diversificada, bastantes representam os nativos nus, alguns procuraram "embelezar" os nativos, com acessórios (penas nas cabeça) e pinturas no corpo, conforme as bandas desenhadas exploradas. Outros ilustraram os nativos de uma forma tão primária, que foi necessário o auxílio do texto verbal, para conseguir descodificar qual era a ação que estava a ser retratada naquela vinheta. No entanto, constatou-se que os representavam como sujeitos históricos pacíficos, que acolheram bem os portugueses.

Relativamente à categoria vegetação, podemos verificar que nenhum dos alunos fez referência às plantas existentes neste território, ao nível do texto verbal. Por outro lado, apenas doze alunos apresentam nas suas ilustrações alguma vegetação. Por exemplo o aluno A3 apresenta na vinheta 2, cinco coqueiros, ao qual um português exclama: "Cocos!". Contudo, durante a exploração da "descoberta" do Brasil, nunca foi referenciado este tipo de árvore, possivelmente pode expressar uma conceção alternativa do aluno que associa o Brasil ao coqueiro, árvore de fruto tropical.

$\mathrm{Na}$ última categoria de análise, apenas dois alunos mencionam, quer no texto verbal como no pictórico, um conjunto de produtos, que supostamente os portugueses trouxeram do 
Brasil, durante aquela descoberta. No entanto, é evidente o anacronismo que estes alunos evidenciam pela falta de perspetiva contextualizada por parte dos alunos, pois referem produtos que só muito mais tarde serão trazidos pelos portugueses como o açúcar, o ouro, o tabaco e o cacau, possivelmente influenciados pela informação do manual.

\section{Considerações Finais}

Este projeto pretendeu averiguar as potencialidades que as bandas desenhadas históricas apresentam como recurso didático e fonte historiográfica, no ensino da História. Neste artigo, foi-nos possível apresentar uma breve resenha, de algumas visões de investigadores nacionais e internacionais que, ao longo do tempo, têm investigado sobre este género literário, aplicado em contexto de sala de aula no ensino de História.

Este estudo veio demonstrar que as bandas desenhadas históricas detêm uma grande riqueza, nos seus textos narrativos e ilustrativos, que permitem aos alunos adquirirem e desenvolverem os seus conhecimentos históricos. De acordo com os resultados obtidos da análise dos dados recolhidos dos instrumentos aplicados (instrumentos 2 e 3) foi possível averiguar que os alunos conseguiram enriquecer o seu conhecimento histórico através das obras exploradas, tendo a perceção que havia uma diferenciação do conteúdo histórico sobre a "descoberta" do Brasil. Contudo, esta atividade não consistia em averiguar a veracidade de cada obra, uma vez que Lee (2001), Barca e Gago (2004) alertam que a análise de várias fontes históricas, sobre o mesmo conteúdo histórico pode criar algumas controvérsias em contexto de sala de aula. Para isso, criou-se após a realização da ficha de comparações (instrumento 2), um momento de "debate", para demonstrar que ambas as obras apresentam um grande rigor histórico do acontecimento, porém a seleção dos vários acontecimentos pelos autores das BDs foi diferenciada, com visões diferentes, os autores brasileiros basearam-se na carta de Pero Vaz de Caminha a El-Rei D. Manuel, e por isso, exibem maior conteúdo histórico, enquanto que a versão portuguesa é mais parca em pormenores, pois este é apenas um acontecimento de entre outros da expansão ultramarina portuguesa expresso neste volume da BD e por isso menos desenvolvido. Neste sentido, esta atividade permitiu apurar que os nossos alunos conseguiram ter uma opinião "critica" sobre o rigor histórico, ao nível ilustrativo/narrativo e cronológico, como defendem os autores Guay e Charrette (2009) citado por Gonçalves (2013). Conseguiram de certa forma aperceber-se que a interpretação histórica de um acontecimento pode ser condicionada por vários fatores, desde a tipologia de fontes usadas pelos autores, a intencionalidade dos autores e de como interpretam as fontes, as questões que colocam às fontes e como as interpretam e contextualizam, bem como os contextos de produção das obras, tudo isto pode condicionar a existência de interpretações e 
visões diferentes sobre o mesmo acontecimento. Chapman (2018, p. 120) adverte que para percebermos como as interpretações diferem umas das outras "precisamos distinguir entre os fatores que podem moldar as interpretações e o que as interpretações afirmam- é possível, por exemplo, que textos com formas diferentes promovam afirmações essencialmente idênticas, e vice-versa".

No que diz respeito às construções das bandas desenhadas sobre a descoberta do Brasil, os nossos alunos conseguiram mobilizar conhecimento histórico, uma vez que nas suas construções foi-nos possível aferir referências aos recursos disponibilizados, nomeadamente as bandas desenhadas exploradas, biografias e aprendizagens obtidas com a visita de estudo. Esta dinâmica teve um grande êxito com os nossos alunos, uma vez que fugiu ao tradicionalismo das aulas expositivas, que as nossas crianças estão habituadas a encontrar nas suas salas de aula. De acordo com a análise de dados, podemos averiguar que a categoria espacial, temporal e o tipo de embarcação utilizada pelos navegadores portugueses foram aquelas que tiveram mais sucesso, uma vez que eles demonstraram nas suas construções uma grande capacidade de explicitar, relatar todos os acontecimentos, mostrando assim competências ao nível da compreensão histórica e temporal, tendo como apoio a datação dos acontecimentos. Neste sentido, podemos concluir que o conteúdo histórico presente nas bandas desenhadas permitiu aos alunos enriquecerem as suas aprendizagens históricas, assim como, adquirirem algumas capacidades ao nível da interpretação e da compreensão histórica, no entanto alguns alunos demonstram algumas carências na explicitação do conhecimento adquirido, em parte justificado, pela construção de BD implicar outras competências, nomeadamente no domínio das expressões plásticas e da língua.

Em suma, podemos aferir que a utilização da banda desenhada histórica como recurso pedagógico e fonte historiográfica é de extrema riqueza e de grande pertinência, na abordagem dos conteúdos históricos, pois estimula os alunos para o ensino da História, bem como, a construção de melhores aprendizagens.

\section{Referências}

BARCA, Isabel. Para uma educação histórica de qualidade. In: JORNADAS INTERNACIONAIS DE EDUCAÇÃO HISTÓRICA, 4., 2004, Braga. Anais [...]. Braga: Universidade do Minho, 2004. p. 131-144.

BARCA, Isabel; GAGO, Marília. Usos da narrativa em História. In: ENCONTRO SOBRE NARRATIVAS HISTÓRICAS E FICCIONAIS, 1., 2004, Braga. Anais [...]. Braga: Universidade do Minho, 2004. p. 29-40. 
BONIFÁCIO, Selma. Histórias e $(m)$ quadradinhos: análise sobre a História ensinada na arte sequencial. 2005. Dissertação (Mestrado em Educação) - Universidade Federal do Paraná, Curitiba, 2005.

CHAPMAN, Artur. Interpretações históricas. In: CHAPMAN, Artur. Desenvolvendo o pensamento histórico. Curitiba: W. A. Editores, 2018. p. 109-127.

CORBIN, Juliet; STRAUSS, Anselm. Basics of qualitative research: techniques and procedures for developing grounded theory. Thousand Oaks: Sage, 2008.

COUTINHO, Clara et al. Investigação-acção: metodologia preferencial nas práticas educativas. Revista Psicologia, Educação e Cultura, Vila Nova de Gaia, v. 13, n. 2, p. 355-379, 2009.

ERICKSON, Frederick. Qualitative methods in research on teaching. In: WITTROCK, Merlin Carl (ed.). Handbook of research on teaching. 3rd ed. New York: MacMillan, 1986. p. 119-161.

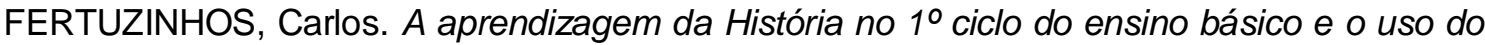
texto prosa e da banda desenhada: um estudo com os alunos do $4^{\circ}$ ano de escolaridade. 2004. Dissertação (Mestrado em Supervisão Pedagógica de História e Ciências Socias) Universidade do Minho, Braga, 2004.

FOSNOT, Catherine. Construtivismo e educação: teoria, perspectivas e práticas. Lisboa: Piaget Editora, 1996.

FRONZA, Marcelo. A intersubjetividade e a verdade na aprendizagem histórica de jovens estudantes a partir das histórias em quadrinhos. 2012. Tese (Doutorado em Educação) Universidade Federal do Paraná, Curitiba, 2012.

FRONZA, Marcelo. O significado das histórias aos quadradinhos na educação histórica dos jovens que estudam no ensino médio. 2007. Dissertação (Mestrado em Educação) Universidade Federal do Paraná, Curitiba, 2007.

GAGO, Marília. Concepções dos alunos acerca da variância da narrativa histórica: um estudo com alunos em anos iniciais do $2^{\circ}$ e $3^{\circ}$ ciclos do ensino básico. 2001. Dissertação (Mestrado em Educação) - Universidade do Minho, Braga, 2001.

GONÇALVES, Armanda. A leitura e interpretação da banda desenhada histórica e os desenhos na expressão dos conhecimentos geográficos. Relatório de Estágio. Braga: Universidade do Minho, 2013.

LAMEIRAS, João; BOLÉO, João; SANTOS, João. Uma revolução desenhada: o 25 de abril e a BD. Santa Maria da Feira: Edições Afrontamentos, 1999.

LEE, Peter. Progressão da compreensão dos alunos em História. In: JORNADAS INTERNACIONAIS EM EDUCAÇÃO HISTÓRICA, 1., 2001, Braga. Anais [...]. Braga: Universidade do Minho, 2001. p. 13-23.

MOTA, Ana. A banda desenhada como representação gráfica-verbal na aprendizagem de História e Geografia. Relatório de Estágio. Braga: Universidade do Minho, 2012.

OLIVEIRA, Cláudia Cavalcante Cedraz Caribé de; SOUZA, José Antônio Correia de. Arte am quadrinhos: a perspectiva do ensino de histórias em quadrinhos na aula de arte. 2013. Monografia (Licenciatura em Artes Visuais) - Universidade do Estado da Bahia, Salvador, 2013. 
PEREIRA, Mariana. A banda desenhada como recurso didático para desenvolver a compreensão leitora e a expressão escrita, na aula de língua. Relatório de Estágio. Braga: Universidade do Minho, 2013.

REGO, João. Çufo ou A Aventura de um Nome. In: ENCONTRO SOBRE NARRATIVAS HISTÓRICAS E FICCIONAIS, 1., 2004, Braga. Anais [...]. Braga: Universidade do Minho, 2004. p. 41-57.

REIS, António do Carmo; GARCÊS, José. A grande aventura: por mares nunca dantes navegados. Porto: Edições ASA, 1992.

SANTOS, Roberto; VERGUEIRO, Waldomiro. Histórias em quadrinhos no processo de aprendizado: da teoria à prática. Eccos, São Paulo, v. 27, p. 81-95, 2012.

SCHMIDT, Maria Auxiliadora; MARTINS, Estevão (org.). Jorn Rüsen: contribuições para uma teoria da didática da História. Curitiba: W. A. Editores, 2016.

SIMÕES, Henrique; GONZAGA, Reinaldo. O achamento do Brasil: a carta de Pero Vaz de Caminha a El-Rei D. Manuel. Ilhéus: Editus, 2000.

SOLÉ, Glória. A banda desenhada histórica como recurso didático-pedagógico para a construção de conhecimento histórico dos alunos no 1ํㅡ. CEB. In: AZEVEDO, Fernando; BALÇA, Ângela; SILVA, Sara (coord.). Globalização na literatura infantil: vozes, rostos e imagens. Raleigh: Lulu Entreprises, 2011. p. 357-390.

SOLÉ, Glória. A História no $1^{\circ}$ ciclo do ensino básico: a concepção do tempo e compreensão histórica das crianças e os contextos para o seu desenvolvimento. 2009. Tese (Doutorado em Estudos da Criança) - Universidade do Minho, Braga, 2009.

SOLÉ, Glória. A primeira república na literatura infanto-juvenil: a ficção histórica na construção do pensamento histórico. In: ENCONTRO NACIONAL DE INVESTIGAÇÃO EM LEITURA, LITERATURA INFANTIL E ILUSTRAÇÃO, 9., 2013, Braga. Anais [...]. Braga: Universidade do Minho, 2013. p. 364-388.

VERGUEIRO, Waldomiro; PIGOZZI, Douglas. Histórias em quadrinhos como suporte pedagógico: o caso Watchmen. Comunicação \& Educação, São Paulo, v. 18, n. 1, p. 43-63, 2013. Disponível em: http://www.revistas.usp.br/comueduc/article/view/69247/71708. Acesso em: 15 jan. 2015.

ZINK, Rui. Banda desenhada portuguesa contemporânea. 1997. Tese (Doutorado em Estudos Portugueses) - Universidade Nova de Lisboa, Lisboa, 1997.

ZINK, Rui. Literatura gráfica? Banda desenhada portuguesa contemporânea. Oeiras: Celta Editora, 1999. 